\title{
Resource integration for co-creation between marketing agencies and clients
}

\begin{abstract}
Resource integration is a central idea within Service-Dominant Logic, but there has been little empirical research on this aspect of theory. This study explores resource integration between marketing agencies and their clients. Nine case studies were developed, using a dyadic approach, of interviewing clients and members of their agency teams. This was followed up with presentations and workshops with over 200 practitioners that validated the findings and added new perspectives. The key operant resources in the client/agency context were identified. The study suggests that resource enhancement and development, as a result of integration, is important. For agency/client research, resource integration and development brings new perspectives complementing existing relationship approaches to research. The findings have implications for relationship marketing theory across B2B contexts and the discourse of co-creation suggests a way for practitioners to discuss how to work together effectively.
\end{abstract}

\subsection{Introduction}

This study is the first to apply ideas from Service-Dominant Logic (S-D Logic) to the empirical context of co-creation between marketing agencies and their clients who work together to create an output, such as a campaign or a design. From a managerial perspective, it is a very important process that is central to producing effective marketing communications. From a theoretical perspective the contribution is mid-range in providing a bridge from metatheory to a context of application, as called for by Vargo and Lusch (2017).

From the start, Vargo and Lusch (2004) recognised the importance of the resources of supplier and customer in the co-creation of service. As the debate has developed, the significance of resource integration between participating actors has become more apparent, particularly in Business-to-Business (B2B) contexts. However, to date there has been limited scholarly research on operant resources and resource integration (Payne et al., 2008; Madhavaran, et al., 2014). In particular, there has been a lack of empirical studies, with most of the work having been at a level of abstraction far removed from practical analysis (Gronroos and Ravald, 2011; Gummeson, 2011) and yet Vargo and Lusch (2011) put forward S-D Logic as an explanation of markets that should ultimately inform the practice of 
marketing. While some recent studies have begun to examine co-creation in different contexts (Frow, McColl-Kennedy and Payne, 2016; Skalen and Edvarrson, 2016; Whalen and Akaka, 2016; Wood, 2016) there has been little contextual research relating to resource integration.

The initial data was derived from interviews with clients and executives from their agencies. This was followed up by face-to-face presentations and workshops with a large number of agency and client practitioners. The transcripts from these workshops were analysed and contribute contextual data to the Discussion and Managerial Implications section.

This article starts by discussing the literature on SD-Logic to demonstrate the theoretical framing of the research around resource integration. This leads to three research questions (RQs): RQ1 what are the key operant resources in the context? RQ2 what happens to resources through integration? RQ3 how do the actors perceive the process and outcome of resource integration? The client/agency relationship is then discussed to demonstrate why it is a good context for looking at co-creation and to explain why S-D Logic is a useful lens to view the phenomenon. The Methodology section outlines the dyadic approach in developing the case studies and the subsequent workshops, involving sharing of the findings and getting feedback from over 200 practitioners. The Findings and Discussion sections elaborate on the operation of resource integration in co-creation, adding to knowledge on the application of S-D Logic and on co-creativity between agencies and their clients. Finally, good theory should inform practice and new perspectives from researching both agency and client perceptions are offered to inform the ways that agencies and clients could work together more effectively. 


\subsection{S-D Logic, co-creation and resource integration}

The fundamental idea behind S-D Logic is that value is co-created through use and can only be understood in terms of the experience of the participants (Vargo and Lusch, 2008a). While the original conceptualisation of S-D Logic viewed these participants as customers and suppliers (Vargo and Luch, 2004), later thinking moved on to consider value to be co-created amongst a range of generic actors (Vargo and Lusch, 2011; Vargo and Lusch, 2016). It may involve a complex series of interactions (Gronroos, 2011), reciprocity (Ballantyne et al., 2011; Ford, 2011) and a number of stakeholders (Frow and Payne, 2011).

This approach, of seeing value as a perception that is relative and individual is given continuing emphasis in S-D Logic, forming Axiom 4: "Value is always uniquely and phenomenologically determined by the beneficiary" in Vargo and Lusch's (2014) update of the core ideas. The implications of Axiom 4 for researching B2B situations and particularly agencies and clients, are significant and yet there has been little empirical research in this area. For example, Axiom 4 underlines the need to consider perspectives from different points of view and yet the contemporary body of literature on marketing agencies and clients (see below) is mostly based on researching one perspective, using either agency or client respondents. The implication of SD-Logic is of the need to conduct empirical research on agencies and clients from both perspectives.

S-D Logic also has much to say about the value generating activities that take place within co-creation, focussing on the nature of the resources provided by the actors and the way operant resources are integrated (Kleineltankamp et al., 2012). Operant resources are usually intangible, such as knowledge and skills (Vargo and Lusch, 2004; Arnould et al., 2006). Whenever a person acts they need some skill or knowledge, so they use operant resources and integrate these by engaging with others in co-creation (Löbler, 2011). Hence, 
resource integration is the means by which value is created (Vargo and Lusch, 2011) and as Axiom 3 states: "All economic and social actors are resource integrators" (Vargo and Lusch, 2014). There is much to learn about resources and resource integration. Madhavaran et al. (2014) note that scholarly work on operant resources has not progressed significantly despite the recognition of their importance. Vargo and Lusch (2004) suggest that new resources can come into being, as a result of co-creation (Vargo and Lusch, 2011). This raises questions about the pre-existence of resources against their creation as a result of integration (Löbler, 2013). As S-D Logic discourse has developed, it has become apparent that there is a knowledge gap in relation to the way operant resources are created, transformed or modified in the process of integration. In view of the limited work in this area, Kleinaltenkamp and collaborators (Kleinaltenkamp et al. 2012) followed up discussions from the S-D Logic Forum on Marketing and Markets (2010) in theorising themes relevant to gaining a clearer understanding of resource integration.

\subsection{A resource integration framework}

The framework proposed by Kleinaltenkamp et al. (2012) has been adapted, in this article, to provide a basis for analysing resource integration.

\section{Insert Figure 1 about here}

Using the framework in Figure 1, the following research questions (RQs) were posed to guide the research study:

RQ1 what are the key operant resources in the context? RQ2 what happens to resources through integration? RQ3 how do the actors perceive the process and outcome of resource integration?

The starting point is to identify the key operant resources that are important in the particular context (RQ1). The process of resource integration has the potential to create 
new resources and change existing resources (Vargo and Lusch, 2011), therefore it is relevant to ask the question ( $R Q 2)$ with regard to understanding what happens to resources through integration. The whole process can be seen from an objective perspective in relation to the interactions of the actors, but also can be viewed as emergent and subjective (Peters et al., 2014). The human and social experiences resulting from resource integration (Ramaswamy, 2011) will form the phenomenological value perceptions of the resource integrators (Vargo and Lusch, 2008a). Therefore understanding how different actors view the process and outcomes (RQ3) is important.

Resource integration can be seen to require engagement between actors. While cocreation of value is the purpose of economic exchange (Vargo and Lusch, 2017), engagement between actors provides the means for co-creating value (Ramaswamy, 2011), through resource integration. Thus the engagement behaviours of the actors (Prior and Marcos-Cuevas, 2016; Waseem, Biggemann and Garry, 2017) are significant in moderating the actors' perceptions of the process and outcomes from co-creation (RQ3).

\subsection{Agencies and clients: A co-creative professional relationship}

The context for the research is that of marketing agencies and their clients working in a co-dependent relationship. A recent literature review of the extant research on marketing agency - client relationships identified co-creation as a key theme for future research to develop stronger theoretical foundations in this area (Keegan, Rowley and Tonge, 2017).

Creativity resources in agencies are largely made up of creative people working in teams within supportive organisational processes (West, 1993; Lynch and West, 2017). Advertising creativity is distinguished from other more pure forms of creativity because it is moderated by the needs of the client (Haberland and Dacin, 1992; Koslow et al., 2003). 
Therefore, clients have a major influence on creative risk taking (West, 1999) and thus creativity becomes a balancing act between agency and client relating to how much risk a client is willing to take (Sasser et al. 2013). Clients who show they are more open to new ideas will receive more creative work (Koslow, 2015). The role of the client is therefore important, but there is a gap in research in understanding the viewpoints of both agency and client on what they put into the creative process and what they get out of the process (Amabile, 1996; Hill and Johnson, 2003; Oliver and Ashley, 2012). In one of the few studies that have attempted to get views on creativity from both agencies and their clients Michell (1984) found several areas of discord. Dissatisfaction with agency performance causes clients to change their advertising agencies despite the costs involved (Michell, Cataquet and Hague, 1992; Durden et al. 1997).

Studies of client dissatisfaction, with their advertising agencies, suggest that agencies are perceived by their ex-clients as being generally poor at managing their side of the relationship (Doyle et al. 1980; Michell, 1986; Michell et al. 1992; Durden et al. 1997). The building of trust in the relationship between agency and client is an important research theme (Caceres and Paparoidamis 2007; Duhan and Sandvik 2009). Relationship development studies have identified the stages of relationships and the emergence of relational bonds such as trust and commitment through a process of open communication and goal setting, adaptability, and coordination (Wackman and Salmon, 1986; Halinen, 1997; Duhan and Sandvik, 2009). Interpersonal relationship studies have identified the importance of friendships and the pivotal role of the agency account manager in building trust (Ewing et al., 2001; Haytko, 2004; Vafeas, 2010). Relationship performance studies have highlighted the need for agency proactivity, productive interaction and client 
involvement (Labahn and Kohli, 1997; Davies and Prince, 1999; Beverland et al., 2007; Grant et al. 2012).

The quality of relationship is important in working effectively together, but there is still a gap in knowledge in relation to the contribution of agency and client actors in different circumstances. The development of marketing campaigns between agencies and clients can be seen to be a prime example of co-creation: "marketers, copywriters, and graphics artists must work closely together to produce a single integrated work" (Wageman and Gordon, 2005, p. 687). At a minimum, this requires client engagement at the beginning of the process in setting the strategic context for the work (Hackley, 1998). However, the level of client engagement with the agency, over and above this, may vary significantly (Haytko, 2004). Na et al., (2009) suggest that the client is closely engaged with strategy and creative work approval, but the extant studies do not explore client engagement at other stages of the process. Creativity is delivered in an interactive process with the client and needs to be understood as a sequence (Hill and Johnson, 2003, 2004). Turnbull and Wheeler (2015) identify 24 stages in the creative process and admit that there is limited understanding of how far the client might be engaged at each stage. Analysing the process at the level of the operant resource integration has the potential to add to knowledge in this area. The importance of the application of both client and agency resource in this process is acknowledged (Koslow et al. 2006), but there has been little research on the nature of these resources (RQ1).

The quality of client input is also important because the wrong type of client input can inhibit the agency's creativity (Hill and Johnson, 2004). Judging creativity is challenging for some clients, requiring fine judgements on when highly creative advertising is appropriate (Sasser et al., 2013). Furthermore, many clients are unsure of the role they 
should play when working with creative agencies (Beard, 1996; Zolkiewski, et al., 2008) and do not understand the process of developing advertising (Feldwork, 2012). Koslow et al.'s (2006) research, with US advertising agencies, suggests that the value of client involvement, in boosting creativity, depends on the client's willingness to be open minded to new ideas. The open minded client can influence the agency environment (Sasser and Koslow, 2008) and in turn motivate everyone in the agency to do great creative work (Koslow, 2015). RQ2 and RQ3 address the question of client and agency input, taking a resource integration approach. RQ2 poses the question of what happens to operant resources during integration when interaction between client and agency results in the creation of outputs in the form of a creative solution or campaign. This covers the creative process, running from briefing through to execution and evaluation. RQ3 investigates the actors' personal perceptions of how they view their contributions and the outputs from this process.

The need for empirical research into the views of both clients and agencies on their contribution to the process is relevant because of the way that the marketing communications environment has fundamentally changed (Keller, 2009) since Michell's (1984) dyadic study. The emergence of websites, e-mail marketing, text marketing and paid search (Keller, 2009), alongside social media and blogging (Kietzmann et al. 2011; Valos et al. 2016) has impacted significantly on the agency/client eco-system (Hennig-Thurau et al. 2010; Karjaluoto et al. 2015; Keller, 2016). In 2015, digital marketing captured $41.3 \%$ of U.S. agency revenue (Johnson, 2016).

The thinking on co-creation and resource integration from the S-D Logic stream of literature can add new perspectives to understand the contribution of clients and agencies and a re-examination is particularly appropriate given the changes in the communications 
environment. The S-D Logic discourse has provided new thinking that has previously not been applied to the agency/client context and the purpose of this article is to explore the contribution that SD-Logic can make to understanding co-creation in this empirical context.

\subsection{Methodology}

There are epistemological and ontological challenges in researching questions using an S-D Logic lens. A positivistic approach to the research was rejected, as being unsuitable for analysing value creation from multiple perspectives. Fundamentally, the phenomenological nature of value perception, in Axiom 4 (Vargo and Lusch, 2014), suggests research approaches that accept that reality is partly socially constructed and that multiple perceptions of reality exist. In this respect, a number of different approaches may be appropriate to research on co-creation, such as critical realism, social constructionism, poststructuralism and others.

The authors chose to take a critical realist approach, as advocated by Van de Ven (2007) for engaged scholarship, because it is suited to understanding of the complex world in which clients and agencies operate, where validity is very much contingent on the context and there are multiple perceptions of reality. The paradigm accepts the existence of a social world and recognises the limitations in our understanding of complex phenomena (Guba and Lincoln, 1994; Godfrey and Hill, 1995; Tsoukas, 1989). Most importantly, critical realism positions the role of the researcher as one of trying to understand an outside reality involving different stakeholders with potentially contradictory perspectives (Healy and Perry, 2000).

Qualitative research methods are well accepted within critical realism and face-toface interviews are considered to be a good way to achieve sufficient depth (Healy and Perry, 2000; Sammarra and Biggiero, 2008). Purposive sampling was used to recruit client 
organizations of varying size. 150 marketing directors and marketing managers from a database of firms that purchase advertising and design services were invited to participate. For practical reasons the sample was limited to the south of the UK. Although the response rate was low (4.7\%), acceptances were received from firms with annual turnover ranging from $f 25 \mathrm{~m}$ to $\mathrm{f} 800 \mathrm{~m}$, and with relationships ranging from 18 months to 10 years. In the first place, clients were approached and once the client agreed to take part their agency was approached. Thus the dyads were formed between each client and their agency. Twenty five interviews were conducted with seven clients and eighteen agency executives. Two of the clients gave the authors access to two of their agencies and so nine separate cases were constructed, based on the relationship between a client and an agency. Restricting the interviews to situations where the authors could get both agency and client respondents limited the response. However, the dyadic nature of the case studies was fundamental in getting viewpoints from both sides and is a distinctive feature of the research.

The validity of the research comes from accessing knowledgeable interviewees (Rubin and Rubin, 1995) to provide context rich data that enhances insight and understanding (Silverman and Marvasti, 2008). Appropriate case studies are particularly useful where new perspectives are sought about an area in context in order to develop new in-depth insights (Johnson et al., 1999; Ghauri and Gronhaug, 2002). The 25 interviews covered recurring themes and data saturation suggested that further information would not be attained by undertaking more interviews.

Table 1 outlines the nature of the clients and agencies to demonstrate the contextual richness and breadth of the multiple cases.

\section{Insert Table 1 about here}


The one-to-one, semi-structured face-to-face interviews used separate topic guides for clients and for agency personnel. The interviews were designed to get the interviewees to talk openly about specific recent projects and the interviewers did not specifically mention resource integration to the interviewees. Table 2 provides the topic guides.

\section{Insert Table 2 about here}

The interviews lasted between 45 and 75 minutes, and were conducted, recorded, transcribed, and analysed, by the researchers. The dyadic nature of the research is important. Perspectives from client-agency pairs were sought because the various actors involved in a relationship may have very different perspectives (Lewis and McNaughton Nicholls, 2014). Each interview was conducted individually, separately and in confidence, with a promise that the interviewee would by quoted anonymously in any published material. The replies of the client and agency were not shared between the counterparties. This was essential in getting open and honest answers because neither client nor agency could be depended on to be totally frank in front of their counterparts, especially if they were dissatisfied. In all but one case (Case 3), the interviewees included the client, an account manager or account director (client services), and a member of the agency's creative studio. It was important to capture the views of agency managers and agency creatives, because of their very different roles and also because of their different value systems (Kover and Goldberg, 1995). In two cases, the client recommended that we speak to two of their agencies because of their contrasting relationship dynamics.

Nvivo 10 was used for coding, following an analytic process based on Pratt et al. (2006) and Gioia et al. (2012). Initially a particularly 'rich' transcript from each respondent type was selected and analysed, line by line, to develop an initial list of first-order concepts. These concepts emerged directly from the interviewee's discussion of recent projects. This 
task was conducted independently by two of the researchers. The two lists of concepts were then compared in order to identify similarities and differences and refine the list. This process of checking the coding improves reliability and definitional clarity (Miles and Huberman, 1994). With the coding of subsequent transcripts the set of concepts expanded. Once the initial coding process was completed the researchers categorised the concepts into higher-order, aggregate constructs. Therefore, while lower-order concepts are descriptive, such as: "Inexperienced clients often don't know what information agencies need" the higher-order constructs, in this case "client knowledge" and ultimately the theoretical dimension "operant resources" are more abstract and more related to theory.

Building on the original research, the authors then shared the findings with practitioners in three face-to-face workshops and then eight workshops with individual agencies, as summarised in Table 3. The face-to-face workshops were organised in coordination with professional bodies, representing clients and agencies. The professional bodies were important in encouraging their members to take part and the participants paid to attend. The format covered presentations of the research findings by the authors, followed by group discussions and feedback relating to implications and actions that could be taken to improve the ways in which clients and agencies work together. The individual agency workshops involved presentation of the research results to creative, account management and other executives followed by a discussion of implications in relation to that particular agency.

\section{Insert Table 3 about here}

These workshops and presentations with over 200 practitioners were recorded and analysed to add contextual understanding and to aid interpretation of the findings from the case studies. This opportunity to utilise tacit practitioner knowledge in considering the 
research findings has informed the following discussion and in particular the managerial implications section.

\subsection{Findings}

The presentation of the findings, from the nine case studies, is structured around the three research questions, as indicated in the sub-headings.

\subsection{The key operant resources in the context (RQ1)}

The research provided rich information on the perceptions of the actors of the operant resources provided. Table 4 summarises and explains the main operant resources mentioned by the interviewees, in talking about how they work with each other. The quotes provided below have been chosen to illustrate and to bring to life the points made by the interviewees.

\section{Insert Table 4 about here}

Initiation of a project tends to come from the client and involves a briefing process. Typically knowledge of the organisation, the strategy, the brand and the customer are required for input into the brief. Hence with an agency new to the client's organisation a large degree of input is required of operant resources from the client:

"Yes. With a new agency, they tend to make big assumptions. There are key learning curves. Agency name made assumptions about our target audience. They assumed it was younger than it was and so their creative work at the beginning was not right. They've had to re-adjust. We've done some work with them since then ........ So they've had to adjust the tone of voice." Client Case 6/7

In contrast, with an incumbent agency this knowledge has often already been taken on board by the agency. This suggests a learning process has taken place in which the 
agency has enhanced its operant resources in relation to that client, as a result of earlier resource integration:

"But we have had a long relationship with agency name. They know the brand well, they understand the industry and the background to why we are doing things so we don't need a detailed written brief." Client Case 2

“But they've been involved in a wide range of projects over five years. So, for smaller projects, I don't have to give them much detail. They know what they need to do. Even with bigger jobs, they know the brand and the target audience." Client Case 6/7

Thus the degree of existing agency operant knowledge, relating to the client organisation appears to be an important factor in the operant resource inputs that are required in briefing. However, the practice of briefing is also very dependent on the attitude and knowledge of the client and in terms of resource inputs appears to vary widely. There were many critical comments from agencies about the quality of briefs and this was often attributed to lack of relevant experience amongst clients:

"Some clients are very much, they write the brief, they give us the brief and say this is what we need done. Some, we go in and they say 'we've got a rough idea of what we want to do' and then we do a brainstorm with the client. And what we find with that, is that we effectively write the brief with them and learn more about what outcomes they want." Agency: Creative Director Case 7

"Another issue is when they don't share all their information with us....... They don't tell us what the PR agency is doing or what they're doing above the line. They just think about pots of budget. There's no synergy." Agency: Account Manager Case 8 The generation of ideas in response to the brief involves the input of creative operant resources from the agency. It is then in the interaction with the client in discussion 
about the ideas/concepts/plans that integration takes place. This requires operant resources from the client in relation to being able to judge and make constructive comments in relation to the work. Despite this confident assertion from the client in Case 1, a number of the clients privately expressed doubts about their ability to judge creative work.

"It's part of a marketing role to be able to understand creativity and expect a certain outcome from what you've briefed in. To write the brief I have to have a certain level of understanding of what I'm looking for." Client Case 1

The ability to make decisions approving creative work and plans in moving ideas and proposals to the next stage is an important point where the agency requires an operant resource from the client. This means getting access to and agreement from the decision maker:

"The only person the agency really listens to in the room is the most senior person. They listen to all this stuff from the client's managers and go 'yeah, yeah' but what the agency really needs is one very clear voice: 'this is what we want'." Client Case 3

“The easiest to work with are those who don't come from a hierarchical organization. If they do, we really need to meet the decision-makers from the outset so that we get some reassurance that they know what they're asking for. It prevents a lot of timewasting." Agency: Account Director Case 7

Producing the outputs from the process requires a range of technical operant resources whether the output is a television advertisement, a pack design, a website or digital campaign. The following quote illustrates a mature and balanced view from an agency design creative summing up how the end product needs to result from the integration of client and agency operant resources: 


\begin{abstract}
"The more you do the job though, you realise you're producing a piece of work for the client's world, about which they know more than we do, so it's a question of balance and compromise. Ultimately, it's not about the designer, it's about the end customer. You have the designer in their world, and the client in their world, but it's about neither of those worlds. It's about the end-customer's world. So it's about combining the knowledge from both sides to reach the customer." Agency: Member of Creative Team
\end{abstract} Case 4

\title{
6.2 Resource integrating: What happens to resources in resource integration? (RQ2)
}

\section{Insert Figure 2 about here}

Figure 2 shows the coding, from the analysis, relating to the concept of resource integration. The second level of coding identifies key stages in the integration process and is broadly in line with other studies that have looked at agency/client engagement as a step by step process (Hill and Johnson, 2004; Na et al., 2009; Turnbull and Wheeler, 2015). The third level of coding identifies the main operant resources, as already outlined in Table 4 . What was evident from the interviews was that way in which the resources are integrated and the balance of contribution between agency and client varies widely.

Taking 'Briefing', in some cases the client may write the brief, in other cases the agency writes with input from the client. Where there is insufficient resource input from the client the agency has to compensate by providing resources to get the project moving:

“It doesn't matter how you get that brief, whether the client writes it, or we write it together....... Either way you need to know what you're trying to achieve and need to be collectively aligned." Agency: Account Director, Case 7.

At the 'Creative development' stage in Figure 2, the client needs to supply operant resources in terms of their "Ability to evaluate creative ideas" through responding to the 
agency's creative work and supplying further direction. The interviews, with clients suggest that this can be particularly challenging. All the clients in the research expressed some degree of concern over judging creative work, as expressed by the client in Cases 6 and 7:

"So I'm not always $100 \%$ confident. Do other people say that?"....Interviewer: “Oh yes...."

"They do? Thank goodness. I always think it's me lacking confidence." Client: Cases 6 and 7.

The 'Creative development' stage involves the fundamental agency operant resource of 'Creative skills'. In the 'Production' and 'Implementation' stages, in Figure 2, the range of operant resources supplied by agencies varies greatly. In the cases, the larger agencies (Cases 3 and 7) offered a more diversified range of capabilities in terms of media buying, research and planning. Across all stages, the resource contribution by different agencies seems to vary in relation to the scope of their expertise and what they perceive to be expected of them by the client company. Case 3 is an example of a large agency that provides a strategic perspective and a wider knowledge of trends, customer issues and media opportunities:

“We don't only do creative output for print, TV and radio, but we're the strategic lead. What that means is we're involved in their annual planning cycle and involved in the upstream process." Agency: Account Director, Case 3.

The degree of resource contribution by agency and client at different stages of resource integration is, therefore, highly variable. What is more interesting though, is the way the available operant resources may develop over time. There was plenty of evidence of how resources develop and are enhanced in the resource integration process. Two experienced clients demonstrated how their own operant resources were enhanced through taking part in the co-creative process with agencies. The client in Case 4 explains 
how she learnt from agencies in her early career. The client in Case 3 recognises that the client bears a major responsibility for the creative output and emphasises the need for continuous improvement and learning in working with agencies:

"Quite often you find yourself as the specialist in your organization, but in the absence of having internal people to learn from, you have to find other ways of learning. A lot of that for me has been through external agencies. Earlier in my career, I had to use agencies as a way of learning." Client: Case 4

"My mantra is that the work is only as good as the client. You need to self-learn in the process. What worked, what didn't work? Where did we go wrong? What do we need to do differently?" Client: Case 3

The integration process therefore is not just about creating new resources (such as a new campaign), as outputs of the resource integration process, but also about modifying (ideally enhancing) the potential resources (for example the capabilities of the actors) that are available for further resource integration over time.

\section{Insert Figure 3 about here}

The idea of developing and enhancing resources adds a parallel process to the step by step process of working together. Figure 3 demonstrates one of the reasons why there are benefits in the establishment of longer term relationships between agencies and clients. Through the resource integration process there is the opportunity to build the potential resources that then go into the next stage of resource integration (the next campaign or project).

\subsection{Actors' perceptions of the process of resource integrating (RQ3)}

Resource integration occurs through a series of interactions between agency and client from briefing, through creative development, to final execution. While both sides may 
agree on the steps in the process they may have very different views on the quality of resource input and subsequent value of the output. The benefit of the dyadic approach in the research is that it shows up differences in perceptions, as demonstrated in these contrasting quotes:

"To write the brief I have to have a certain level of understanding of what I'm looking for. It's not they don't have knowledge of the market, but we have a much better understanding of what customers want, what works in the marketplace, what consumers respond to............ feel they need as much as possible." Client: Case 1

"(Name of client Case 1) for example is one of these woolly briefers. She's very vague. She knows what she wants but can't seem to get it down on paper." Agency: Studio Manager, Case 1

Client attitude and way they deal with the agency is key in terms of the motivation of people working on their account. The agency interviewees suggested that often a compromise is made between providing an output that keeps the client happy and an output that they value as good creative work. The process can have a significant effect on how much the agency feels ownership of the resulting creative work:

"Often the process has an impact on how much people love or hate an ad and therefore how much ownership they feel. If you've been through a good process that everyone is happy with, everyone feels like it's got their name on it. But if you go through a difficult process or end up with an output that misses the bar, the agency doesn't put it on its show reel and the client doesn't want ownership either." Agency: Account Director, Case 3 
When budgets and resources are sufficient, the creation of shared experiences may be possible, as in the case below, where the client provided a joint context for co-creation of the brief:

"We went on a field trip to the Orkney Islands, four or five of us, with the client. Stayed there for a few days, looked round the island, went on a boat trip, and from that trip, we put together a mood board of images that captured the trip. The client turned round and said 'actually that captures the brief. Why don't you design from that mood board?' Although it was then supported by a written brief, that was done retrospectively. We started designing from a shared experience." Agency: Creative Director, Case 2

The degree of openness of the relationship between agency and client is stressed as important in all the cases, in line with previous literature on agency/client relationships (Sasser and Koslow, 2008; Koslow, 2015). The sometimes contrasting experiences of the actors involved in the resource integration process helps explain why this is the case. If the relationship is open and honest the experiences are shared and problems can be dealt with. However, in the cases there was only one example where the interviewees talked about the agency and client sitting down together to review the relationship and process between agency and client. The pattern of working generally seemed to be that agency and client would move from one campaign or project to another without sharing their experience of working together.

\subsection{Discussion}

The purpose of this article is to apply theoretical ideas from S-D Logic to co-creation in a practical business context, in order to use S-D Logic as a lens to provide new perspectives and ultimately inform the practice of marketing. In addition to the case studies, the input from the workshops with over 200 practitioners helped inform this section and the 
rest of the article. The discussion below will consider the implications from the perspective of to the S-D Logic literature and of the literature on marketing agencies and their clients.

\subsection{Contribution to S-D Logic}

The study answers the call for more research on operant resources and resource integration in practice (Payne et al., 2008; Madhavaran, et al., 2014). In making a bridge between meta-theory and application, the research identifies key operant resources in the context of client/agency co-creation. This allows for a consideration of the operant resources used at different points in the resource integration process (Figure 2). Further studies of operant resources in different B2B contexts could usefully compare the types of resources used in co-creation and identify commonalities and differences.

The concept of resource development has received little attention in the S-D Logic literature, and would benefit from further exploration. Vargo and Lusch $(2004 ; 2011)$ talk about the process of 'resources becoming', but there is limited explanation of this (Löbler, 2013; Madhavaran et al., 2014). In the current study, new outputs such as campaigns, advertisements, designs and websites are created through resource integration. What is more interesting though is to consider the effect of resource integration on the development and improvement of the operant resources that the actors bring to the process. Clients in the case studies acknowledged the role that working alongside agencies had played in their professional development, particularly when young and inexperienced. The co-creation process provides the potential for clients to develop their skills with respect to briefing, creative judgement and managing the client-agency relationship, all of which involve the enhancement of their operant resources. Similarly, agency actors develop their operant resources in relation to their knowledge of their client's commercial operation. At the very least, the actors can be seen to develop their professional competence and 
confidence which, in themselves, are operant resources. The operant resource development process can be seen to be very important in ongoing collaborations, where effective learning results in the development of the actors' operant resources, thereby providing an enhanced input into the next round of resource integration, as suggested in Figure 3 . This study suggests that resource development is the way in which resource shortfalls can be corrected and resources may be brought back into balance, over time, in order to enhance the effectiveness of co-creation.

The importance of building trust is well established in B2B relationships (Morgan and Hunt, 1994) and particularly in the relationship between client and agency (Caceres and Paparoidamis 2007; Duhan and Sandvik 2009). The development of operant resources during co-creation would seem to be an important element in the trust building process. As described above, during co-creation the actors can develop their competence through building relevant knowledge and correcting resource shortfalls. In the client/agency context it is particularly incumbent on the agency to correct shortfalls given their dependence on the client as budget holder. The connection between the development of operant resources and building of trust provides a potential link between S-D Logic and the relationship marketing literature. Resource development could be a very promising area for understanding why some B2B relationships are more effective than others. What are the relationship factors that lead to effective operant resource development? How far is effective operant resource development related to the development of trust? Further research is needed on how resource integration can develop the actors' operant resources and how organisations might leverage co-creation opportunities to enhance the operant resources of their actor networks, particularly their employees.

7.2 Contribution to knowledge of agency/client co-creation 
Over the last 20 years there have been a number of studies that have looked at creativity in agencies as a stage-by-stage process (Amabile, 1996; Hill and Johnson, 2004; Na et al. 2009; Turnbull and Wheeler, 2015). Studies have shown a variety of patterns of engagement with clients (Haytko, 2004; Hill and Johnston, 2004; Sasser and Koslow, 2008). The S-D Logic approach has the potential to aid understanding of client involvement by focussing on the contribution that the client and agency make at the fundamental level of operant resources. This focus on what is contributed by each side allows for a wide variation in contribution rather than following preconceived notions of the role of agency and client.

It has been established that role ambiguity can be a source of dissatisfaction in the client/agency relationship (Beard, 1996; Zolkiewski, et al., 2008). The availability and deployment of appropriate operant resources on both sides is highly relevant to obtaining a better understanding of the underlying reasons for the ambiguity. Examples given in the Findings section demonstrate, for example, that briefing can take many forms and may involve a wide variation in client involvement. While the relative resource contribution is a longstanding issue (Beard, 1996), it is also notable that digital marketing has brought in new areas of ambiguity around website development and updating, social media content and control and search engine optimisation. The identification of the key operant resources required at different stages of the co-creation process is of potential significance in understanding how agencies and clients work together in the emerging new communications environment.

The findings, in relation to RQ2, demonstrate how the integration process can lead to the development of the operant resources of the actors, which then provides enhanced resources for the next round of co-creative activities (Figure 3). This shows that resource integration leads to greater benefits than simply achieving a short term goal by putting 
together complementary resources. Resource integration provides opportunities for actors to learn from each other and develop knowledge and skills that will be useful in the future. This is important. The follow up workshops to the original case studies included working group sessions, where the practitioner participants discussed the implications of the findings from the original case studies. The outputs from these groups were recorded, transcribed and analysed. The analysis suggests that resource shortfalls on one side or another are frequent occurrences.

The workshops also confirmed the tendency for agency and client actors to concentrate on the outputs of the process rather than the development of the operant resources of those involved in resource integrating. Previous research on agencies and clients has stressed the importance of the client being open minded to create the conditions for creativity (Koslow et al., 2006; Sasser and Koslow, 2008; Koslow, 2015). A resource integration approach suggests that a more structured process of facilitating reflection and learning would be beneficial in many cases. Imbalances of skills in other knowledge intensive business services have been found to cause problems in co-creation (AarikkaStenroos, and Jaakkola, 2012). Understanding more about how resources develop during cocreation has the potential to bring new insights into how imbalances can be corrected.

Value may be co-destroyed as well as co-created (Ple'and Ca'ceres, 2010; Gronroos and Gummerus, 2014). Recent literature has clarified the idea of a negative side of cocreation by conceptualising the positive and negative results of co-creation as a continuum (Chowdhury, Gruber Zolkiewski, 2016). Value may be diminished because of the action of the actors (Vafeas, Hughes, and Hilton, 2016). Agencies are frequently sacked by clients with the main reason being dissatisfaction with agency performance (Michell et al. 1992; Durden et al. 1997). A focus on operant resources could shed light on the reasons for dissatisfaction. 
While co-creation may lead to the enhancement and development of resources it may also lead to resources becoming redundant over a time period. For example, an agency may be replaced because the client perceives the need for a new creative approach. In this case reason could be that the agency has become complacent or it could simply be that the client has been approached by another agency with new ideas. Creativity is a particularly interesting operant resource in that it is possible that this resource may sometimes diminish over time, as familiarity leads to preconceptions over what approach will be effective and a lack of new ideas.

A striking aspect of the research related to the very different perspectives of the actors in talking about each other's contribution to the resource integration process and its outcomes (RQ3). S-D Logic emphasises the need for value to be understood from the perspective of all the stakeholders because value is perceived differently by the actors involved (Frow and Payne, 2011; Kowalkowski, 2011). One contribution of this study, in contrast to other recent studies, is the dyadic approach in getting both client and agency interviewees to talk about their own experiences of resource integration in relation to the same specific case. Haytko (2004) for example, only interviewed agency account managers. She admits this is a limitation in her study, but suggests that interviewing clients was not an option because advertising agencies are private and very protective of these relationships. The current study demonstrates the benefit of approaching clients in the first place and getting them to sanction an approach to their agency. Approaching future client/agency research in a similar manner may help overcome some of the challenges experienced by Haytko and others.

\subsection{Managerial implications}


The S-D Logic approach to co-creation has the potential to influence practice as well as theory. In reality, establishing a more open dialogue, as recommended in the existing literature, may prove difficult because of the unequal balance of power between agency and client, with the client ultimately holding the budget. The workshop feedback from practitioners suggested that time spent together is becoming more limited and the proliferation of agencies, with the development of digital marketing, is making it more difficult to work together effectively and in an integrated manner. The resource integration approach might provide a language or discourse that could legitimately be used by agencies to talk about the contribution from all sides that is necessary to optimise effectiveness of the co-creation process.

The resource integration framework presents a strong case for widespread adoption of a formal evaluation of co-creation experiences by all collaborating actors. This is more than the client and agency sitting down together to discuss their experience of working together. A resource integration framework provides a mechanism for addressing what resources are required at different stages and how these can best be provided. This focusses the discussion of what is required to a constructive analysis without blaming or criticising individuals.

It also might be the case that the agency is not able to sit down with the client to discuss how to operate more effectively together. In this situation, resource integration still provides a framework for agencies to analyse what could be done to improve performance. The findings on the development of the actors' operant resources during resource integration are highly relevant for understanding how to deal with shortfalls in resource inputs when they occur. The research suggested certain areas, such as in evaluating creative work, which clients found to be very difficult. The client may be highly proficient in the 
technical aspects of running their business, but briefing and judging creative work requires a different set of skills. Clients may be unwilling to admit their lack of expertise to the agency, because the client thinks it would be a sign of weakness and feel that it may lessen their authority. In the follow-up presentations and workshops to the original case studies, the authors' asked the participants how often clients were offered any training on evaluating creative work and the results suggested that it is very rare for training to be offered. Taking a lead on this this may be a way forward for agencies and in positioning this with clients. The language of co-creation may prove a useful starting point.

\subsection{Conclusions}

This exploratory study has utilised theoretical ideas from S-D Logic as a lens to analyse resource integration in the specific context of clients and their marketing agencies. As such, the intended contribution is two-fold. The first contribution responds to calls for empirical studies based on the theoretical ideas of S-D Logic. Specifically, the research explored the key operant resources in the context (RQ1); the development of resources in resource integration (RQ2) and the perceptions of those involved in resource integration (RQ3).

The findings provide some new perspectives on the development of operant resources in the course of co-creation. In particular, the idea of resource development and enhancement, taking place in the process of resource integration and the potential importance of this process to maintaining effective co-creation is a fertile area for empirical research in other contexts. The application of theory from S-D Logic to analysis in context also raised philosophical questions for the authors about the most appropriate research approach to utilise in this field. As previously mentioned, Axiom 4 strongly directs the researcher towards research that investigates the multiple subjective perspectives of the 
participants. Therefore we would assert that participant subjectivity needs to be built in to empirical research on S-D Logic. However, we agree with Peters et al. (2014) that both subjective and objective approaches have a role to play. Particularly, in using objective approaches, as a form of triangulation, to provide separate data to complement the subjective views of the participants. For example, in this study the subjective reports of resource enhancement might have been complemented by more objective assessment of individual capabilities over time. In this regard participant observation, in longitudinal studies, might be a useful approach alongside depth interviews with the actors.

The second contribution is to demonstrate how the ideas and language of S-D Logic can be used to bring new insights to a complex B2B relationship, in this case that of marketing agencies and their clients. The intention is to complement rather than replace the dominant approach of applying relationship marketing theory to the study of agencies and clients. In line with the emphasis in S-D Logic on the phenomenological nature of value perception, the research involved interviewing both clients and agency executives to get their separate perspectives on their common case. Dyadic research is rare in this context. This exploratory study shows that the resources contributed by the actors vary and are not static, but can change and develop over time. There is much to learn about what agency and client actors contribute, in different circumstances and what level and type of resource contribution is effective at different stages to maximise the effectiveness of the creative process. In B2B more generally, co-creation of value between actors, often in wide networks of relationships is fundamental. Building trusting relationships and working effectively together requires resource integration and yet this aspect is not stressed in relationship marketing theory. One of the contributions of this article is to demonstrate how resource integration and the idea of resource enhancement can help build effective working 
relationships. Incorporating resource integration into relationship marketing theory has the potential to bring the fields of S-D Logic and relationship marketing closer together.

Vargo and Lusch's (2008b) view on relationship marketing (RM) is that its establishment was a response to the limitations of the Goods-Dominant Logic. They argue that S-D Logic, in providing a general theory of marketing, enhances and encompasses elements of RM (Vargo and Lusch 2008a). A number of RM academics have written on S-D Logic (Gronroos, 2011; Ford 2011; Ford and Mouzas; 2013; Skjølsvik, 2017) and ideas from RM have influenced the development of S-D Logic. For example, the change from an emphasis on co-creation between customers and suppliers to co-creation between generic actors was influenced by inputs from B2B RM academics (Vargo and Lusch, 2011; Vargo and Lusch, 2016). Thus, the connections between S-D Logic and RM are important in the development of theory. Moreover, Madhavaran, Granot and Badrinarayanan (2014) call specifically for more research into operant resources and their contribution to RM.

The importance of building trust is well established in B2B relationships (Morgan and Hunt, 1994) and particularly in the relationship between client and agency (Caceres and Paparoidamis 2007; Duhan and Sandvik 2009). The present research suggests that the development of operant resources during resource integration is an important element in the trust building process. As described in the Findings section, during resource integration, the actors can develop their competences through building relevant knowledge and correcting resource shortfalls. In the client/agency context, it is particularly incumbent on the agency to correct shortfalls, given their dependence on the client as budget holder. The connection between the development of operant resources and building of trust provides a potential area for more research connecting S-D Logic and the RM literature. Specifically, the concept of resource development could be a very promising area for understanding why 
some B2B relationships are more effective than others. Conversely, it would be useful to understand how relationship factors, such as trust and openness lead to effective operant resource development.

The dynamic of the agency/ client working relationship is a challenging one for both parties. Yet it is highly important to the marketing management role. The role of universities and professional training bodies is significant in respect to developing marketing theory that is relevant and can inform teaching that influences practice. Curricula for undergraduates and postgraduates in vocational subject areas, such as business and marketing and design and creativity, should include an element on agency/client co-creation to prepare the managers of tomorrow for the challenges of working together. S-D Logic provides a perspective on co-creation of value and resource integration that could usefully be adopted in teaching and ultimately in practice, by thoughtful marketing managers and agency executives.

\subsection{References}

Aarikka-Stenroos, L. and Jaakkola, E. (2012), "Value co-creation in knowledge intensive business services: a dyadic perspective on the joint problem solving process", Industrial Marketing Management, Vol 41, pp.15-26.

Amabile, T. M. (1996), Creativity in Context. Westview Press, Colorado.

Arnould, E. J. Price, L. L. and Malshe A. (2006), "Toward a Cultural Resource-Based Theory of the Customer", in Lusch, R. F. and Vargo, S. L. eds. The Service-Dominant Logic of Marketing: Dialog, Debate and Directions, Armonk NY: ME Sharpe.

Ballantyne, D. Frow, P. Varey, R.J. and Payne, A. (2011), "Value propositions as communications practice: Taking a wider view", Industrial Marketing Management, Vol 40 No 2, pp. 202-210.

Beard, F. (1996), "Marketing Client Role Ambiguity as a Source of Dissatisfaction in ClientAd Agency Relationships", Journal of Advertising Research, Vol 36 No 5, pp. 9-20.

Beverland, M. Farrelly, F. and Woodhatch, Z. (2007), "Exploring the dimensions of proactivity in advertising agency-client relationships", Journal of Advertising, Vol 36 No 4, 
pp. 49-60.

Caceres, R. and Paparoidamis, N. (2007), "Service Quality, Relationship Satisfaction, Trust, Commitment, and Business-to- Business Loyalty," European Journal of Marketing, Vol 41 Nos $7 / 8$, pp. 836-67.

Chowdhury, I. N. Gruber, T.B. and Zolkiewski, J. (2016), " Every cloud has a silver lining Exploring the dark side of value co-creation in B2B service networks", Industrial Marketing Management, Vol. 55 pp. 97-109.

Davies, M. and Prince, M. (1999), "Examining the longevity of new agency accounts: a comparative study of US and UK advertising experiences", Journal of Advertising, Vol 28 No 4, pp.75-89.

Doyle, P. Corstjens,M. and Michell,P. (1980), "Signals of vulnerability in client-agency relations", Journal of Marketing, Vol 44 (Fall), pp. 18-23.

Duhan, D. and Sandvik, K. (2009), "Outcomes of advertiser-agency relationships: the form and role of cooperation", International Journal of Advertising, Vol 28 No 5, pp. 881-919.

Durden, G. Orsman, T. and Michell, P. (1997), "Commonalities in the Reasons for Switching Advertising Agencies: Corroboratory Evidence from New Zealand", International Journal of Advertising, Vol 16 No1, pp. 62-69.

Ewing. M. Pinto, T. and Soutar, G. (2001), “Agency-client chemistry: demographic and psychographic influences", International Journal of Advertising, Vol 20 No 2, pp. 169-187.

Feldwork, P. (2012), “The Feldwork Factor: Briefing Agencies”, Admap, May 1-3.

Ford, D. (2011), "IMP and service-dominant logic: Divergence, convergence and development", Industrial Marketing Management, Vol 40 No 2, pp. 231-239.

Ford, D. and Mouzas, S. (2013), "Service and value in the interactive business landscape", Industrial Marketing Management, Vol 42, pp. 9-17.

Frow, P. McColl-Kennedy, J. and Payne, A. (2016), "Co-creation practices: Their role in shaping a health care ecosystem", Industrial Marketing Management, Vol. 56, pp. 24-39.

Frow, P. and Payne, A. (2011), "A stakeholder perspective of the value proposition concept", European Journal of Marketing, Vol 45 Nos 1and 2, pp. 223-240.

Grant, I. McLeod, C. and Shaw, E. (2012), "Conflict and Advertising Planning:

Consequences of Networking for Advertising Planning," European Journal of Marketing, Vol 46 Nos1/2, pp. 73-91.

Ghauri, P. and Gronhaug K. (2002), Research Methods in Business Studies: A Practical 
Guide, Prentice Hall, New York.

Gioia, D. Corley, K. and Hamilton, A. (2013), "Seeking Qualitative Rigour in Inductive Research", Organizational Research Methods, Vol. 16, No. 1, pp. 15-31.

Godfrey, P. and Hill, C. (1995), "The problem of unobservables in strategic management research", Strategic Management Journal Vol 16, pp. 519-533.

Grönroos, C. (2011), "Value co-creation in service logic: a critical analysis", Marketing Theory, Vol 11 No 3, pp. 279-301.

Grönroos C., and Gummerus, J. (2014), "The service revolution and its marketing implications: service logic vs service-dominant logic", Managing Service Quality, Vol. 24, No. 3, pp. 206-229.

Grönroos, C. and Ravald, A. (2011), "Service as business logic: implications for value creation and marketing", Journal of Service Management, Vol 22 No 1, pp. 5 - 22.

Guba, E. and Lincoln, Y. (1994), "Competing Paradigms in Qualitative Research", in Denzin N. and Lincoln Y. (eds), Handbook of Qualitative Research, Sage, California.

Gummerus, J. (2013), "Value creation processes and value outcomes in marketing theory: Strangers or siblings?", Marketing Theory, Vol 13 No 1, pp. 19-46.

Gummesson, E. (2011), "2B or not 2B: That is the question", Industrial Marketing Management, Vol 40 No 2, pp. 190-192.

Haberland, G. S. and Dacin, P. A. (1992), "The Development of a Measure to Assess Viewers' Judgements of the Creativity of an Advertisement: A Preliminary Study", Advances in Consumer Research, Vol 19 No 1, pp. 817-825.

Hackley, C. E. (1998), "Social Constructionism and Research in Marketing and Advertising", Qualitative Market Research: An International Journal, Vol 1 No 3, pp.125-131.

Halinen, A. (1997), Relationship Marketing in Professional Services: A Study of AgencyClient Dynamics in the Advertising Sector, Routledge, London.

Haytko, D. (2004), "Firm-to-firm and interpersonal relationships: perspectives from advertising agency account managers", Journal of the Academy of Marketing Science, Vol 32 No 3, pp. 312-328.

Healy, M. and Perry, C. (2000), "Comprehensive criteria to judge validity and reliability of qualitative research within the realism paradigm", Qualitative Market Research: An International Journal, Vol 3 No 3, pp. 118-126.

Hennig-Thurau, T., Malthouse, E.C. Friege, C. Gensler, S. Lobschat, L. Rangaswamy, A. \& Skiera, B. (2010), "The impact of new media on customer relationships", Journal of Service 
Research, Vol. 13 No. 3, pp. 311-330.

Hill, R. and Johnson, L. W. (2003), "When creativity is a must", Creativity and Innovation Management, Vol. 12, No. 4, pp. 221-229.

Hill, R. and Johnson, L. W. (2004), "Understanding Creative Service: A Qualitative Study of the Advertising Problem Delineation, Communication and Response (APDCR) Process." International Journal of Advertising, Vol 23 No 3, pp. 285-307.

Johnson, B. Advertising Age. 5/2/2016, Vol. 87 Issue 9, p0012-0012. 1p.

Johnston, W.J. Leah, M. and Liu, A. (1999), "Theory testing using case studies in businessto-business research", Industrial Marketing Management, Vol 28, pp. 201-213.

Karjaluoto, H. Mustonen, N. and Ulkuniemi, P. (2015), "The role of digital channels in industrial marketing communications", Journal of Business \& Industrial Marketing, Vol. 30 No 6, pp.703- 71 .

Keegan, B.J. Rowley, J. and Tonge, J. (2017), "Marketing agency - client relationships: towards a research agenda", European Journal of Marketing, Vol. 51, No. 7/8, pp.11971223, https://doi.org/10.1108/EJM-10-2015-0712

Keller K.L. (2009), “Building Strong Brands in a Modern Marketing Communications Environment", Journal of Marketing Communications, Vol 15 Nos 2-3, pp. 139-55.

Keller K.L. (2016), “Unlocking the Power of Integrated Marketing Communications: How Integrated Is Your IMC Program?", Journal of Advertising, Vol 45 No 3, pp. 286-301.

Kietzmann, J.H. Hermkens, K. Mccarthy, I.P. and Silvestre, B.S. (2011), "Social media? Get serious! Understanding the functional building blocks of social media", Business Horizons, Vol. 54 No 3, pp. 241-251.

Kleineltankamp, K. Brodie, R. Frow, P. Hughes, T. Peters, L. and Woratschek, H. (2012), "Resource Integration", Marketing Theory, Vol 12 No 2, pp. 201-205.

Koslow, S. Sasser, L. and Riordan, E. A. (2003), "What is Creative to Whom and Why? Perceptions in Advertising Agencies", Journal of Advertising Research, Vol 43 No 1, pp. 96110.

Koslow, S. Sasser, S. and Riordan, A. (2006), "Marketers get the advertising they need or the advertising they deserve? Agency Views of How Clients Influence Creativity", Journal of Advertising, Vol 35, No 3, pp. 81-101.

Koslow, S. (2015), "I love creative advertising", Journal of Advertising Research, Vol 55 No 1, pp. 5-8.

Kover, A. and Goldberg, S. (1995), "The Games Copywriters Play: Conflict, Quasi-Control; A 
New Proposal", Journal of Advertising Research, Vol 35, No 4, pp. 52-62.

Kowalkowski, C. (2011), "Dynamics of value propositions: insights from service-dominant logic", European Journal of Marketing, Vol 45 Nos 1and 2, pp. 277-294.

Labahn, D. and Kohli, C. (1997), "Maintaining client commitment in advertising agencyclient Relationships", Industrial Marketing Management, Vol 26 No 6, pp. 497-508.

Lewis, J. and McNaughton Nicholls, C. (2014), "Design issues", in Ritchie, J. Lewis J. McNaughton Nicholls, C. and Ormston, R. eds. Qualitative research practice, 2nd ed. London: Sage, pp. 47-76.

Löbler, H. (2011), "Position and potential of service-dominant logic- Evaluated in an 'ism' frame for further development", Marketing Theory, Vol 11 No 1, pp. 51-73.

Löbler, H. (2013),"Service-dominant networks", Journal of Service Management, Vol 24 No 4 , pp. $420-434$.

Lynch, J. and West, D. (2017), “Agency Creativity: Teams and Performance A Conceptual Model Links Agency Teams' Knowledge Utilization, Agency Creativity, and Performance", Journal of Advertising Research. DOI: 10.2501/JAR-2017-006

Madhavaran, S. Granot, E. and Badrinarayanan, V. (2014), "Relationship marketing strategy: an operant resource perspective", Journal of Business and Industrial Marketing, Vol 29 No 4, pp. 275-283.

Morgan R.M. and Hunt, S.D. (1994), "The Commitment - Trust Theory of Relationship Marketing," Journal of Marketing, Vol 58 No 3, pp.20-38.

Michell, P. (1984), "Accord and discord in agency-client perceptions of creativity", Journal of Advertising Research, Vol 25 No 5, pp. 9-25.

Michell, P. (1986), "Auditing of agency-client relations", Journal of Advertising Research, Vol 26, No 6 Page: 29.

Michell, P. Cataquet, H. and Hague, S. (1992), "Establishing the causes of disaffection in agency-client relations", Journal of Advertising Research, Vol 32 No 2, pp. 41-48.

Miles, M. and Huberman, A. (1989), Qualitative Data Analysis, Sage, California.

Na, W. Marshall, R. and Woodside, A. G. (2009), "Decision System Analysis of Advertising Agency Decisions", Qualitative Market Research: An International Journal, Vol 12 No 2, pp. 153-170.

Oliver, J. and Ashley, C. (2012), “Creative Leaders' Views On Managing Advertising Creativity", Journal of Marketing Theory and Practice, Vol. 20 No. 3, pp. 335-348. 
Payne, A. F. Storbacka, K. and Frow, P. (2008), "Managing the co-creation of value", Journal of the Academy of Marketing Science, Vol 36, pp. 83-96.

Peters, L. Lobler, H. Brodie, R. Breidbach, C. Hollebeek, L. Smith, S. Sorhammar, D. and Varey, R. (2014), "Theorizing about resource integration through service-dominant logic", Marketing Theory, Vol 14 No 3, pp. 249-268.

Ple', L. and Ca'ceres, R. (2010), "Not always Co-creation: Introducing Interactional Codestruction of Value in Service-dominant Logic", Journal of Services Marketing, Vol 24 No 6, pp. 430-37.

Pratt, M. Rockmann, K. and Kaufmann J. (2006), “Constructing Professional Identity: The Role of Work and Identity Learning Cycles in the Customization of Identity among Medical Residents", Academy of Management Journal, Vol. 49, No. 2, pp. 235-262.

Prior, D.D. and Marcos-Cuevas, J. (2016), "Value co-destruction in interfirm relationships: The impact of actor engagement styles", Marketing Theory, Vol. 16, No 4, pp. 533-552.

Ramaswamy, V. (2011), "It's about human experiences......and beyond, to co-creation", Industrial Marketing Management, Vol 40 No 2, pp. 195-196.

Rubin, H. \& Rubin, I. (1995) Qualitative Interviewing: The Art of Hearing Data, Sage: Thousand Oaks.

Sammarra, A., and Biggiero, L. (2008), "Heterogeneity and specificity of inter-firm knowledge flows in innovation networks", Journal of Management Studies, Vol 45 pp. 785814.

Sasser, S. L. and Koslow, S. (2008), "Desperately Seeking Advertising Creativity: Engaging an Imaginative 3Ps Research Agenda", Journal of Advertising, Vol 37 No 4, pp. 5-20.

Sasser, S.L. Koslow, S. Kilgour, M. (2013), "Do clients really need highly creative advertising?", Journal of Advertising Research, Vol 53 No 3, pp. 297-312.

Silverman, D. and Marvasti, A.B. (2008), Doing Qualitative Research: A Comprehensive Guide, Sage, California.

Skalen, P. and Edvarrson, B. (2016), "Transforming from the goods to the servicedominant logic", Marketing Theory, Vol. 16, No. 1, pp. 101-121.

Skjølsvik, T. (2017), "The Impact of Client-Professional Relationships in Ex Ante Value Creation: A Service-Dominant Logic Perspective", Journal of Business-to-Business Marketing, Vol 24, No 3, pp. 183-199.

Tsoukas, H. (1989), "The validity of idiographic research explanations", Academy of Management Review, Vol 14 No 4, pp. 551-561. 
Turnbull S. and Wheeler, C. (2015), "The advertising creative process: A study of UK agencies", Journal of Marketing Communications, DOI: 10.1080/13527266.2014.1000361

Vafeas, M. (2010), "Boundary spanner turnover in professional services: exploring the outcomes of client retention strategies", Journal of Marketing Management, Vol 26, Nos 9 and 10, pp. 195-206.

Vafeas, M. Hughes, T. and Hilton, T. (2016), "Antecedents to value diminution: A dyadic perspective", Marketing Theory, Vol.16, No. 4, pp. 469-491.

Valos, M. Fatemeh, H. Casidy, R. Driesener, C.B. Maplestone, V.L. (2016), "Exploring the integration of social media within integrated marketing communication frameworks: Perspectives of services marketers", Marketing Intelligence \& Planning, Vol 34 No 1, pp.19 $-40$.

Van De Ven, A. H. (2007), Engaged Scholarship: A Guide for Organizational and Social Research, Oxford University Press.

Vargo, S.L., and Lusch. R.F. (2004) “Evolving to a New Dominant Logic for Marketing", Journal of Marketing, Vol 68 No 1, pp. 1-17.

Vargo, S.L., and Lusch. R.F. (2008a), "Service-dominant logic: continuing the evolution." Journal of the Academy of Marketing Science, Vol 36, pp.1-10.

Vargo, S.L., and Lusch. R.F. (2008b), "From goods to service(s): Divergences and convergencies of logics." Industrial Marketing Management, Vol 37, pp. 254-259.

Vargo, S.L., and Lusch. R.F. (2011), “It's all B2B....... and beyond: Toward a systems perspective of the market", Industrial Marketing Management, Vol 40 No 2, pp. 181-187.

Vargo, S. and Lusch, R.F. (2014), "Inversions of service-dominant logic", Marketing Theory, Vol 14 No 3, pp. 239-248.

Vargo, S. and Lusch, R.F. (2016), "Institutions and axioms: an extension and update of service-dominant logic", Journal of the Academy of Marketing Science, Vol 44 No 1, pp. 523.

Vargo, S.L. and Lusch, R.F. (2017), "Service-dominant logic 2025", International Journal of Research in Marketing, http://dx.doi.org/10.1016/j.ijresmar.2016.11.001

Wackman, D. and Salmon, C. (1986), "Developing an advertising agency-client relationship", Journal of Advertising Research, Vol 26 No 6, pp. 21-8.

Wageman, R. and Gordon, F. M. (2005), "As the twig is bent: How group values shape emergent task interdependence in groups", Organization Science, Vol 16 No 6, pp. 687702. 
Waseem , D. Biggemann, S. and Garry T. (2017), "Value co-creation: The role of actor competence", Industrial Marketing Management, In press.

https://doi.org/10.1016/j.indmarman.2017.07.005

West, D. (1993), “Cross-national creative personalities, processes, and agency

philosophies", Journal of Advertising Research, Vol 33 No 5, pp. 53-62.

West, D. (1999), "360 degrees of creative risk", Journal of Advertising Research, Vol 39 No 1, pp. 39-50.

Whalen, P.S. and Akaka, M.A. (2016), “A dynamic market conceptualization for entrepreneurial marketing: the co-creation of opportunities", Journal of Strategic Marketing, Vol. 24, No. 1, pp. 61-75, DOI: 10.1080/0965254X.2015.1035040

Wood, M. (2016),"Midstream social marketing and the co-creation of public services", Journal of Social Marketing, Vol. 6, No. 3, pp. $277-293$.

Zolkiewski, J. Burton, J. and Stratoudaki. S. (2008), "The Delicate Power Balance in Advertising Agency-Client Relationships: Partnership or Battleground? The Case of the Greek Advertising Market", Journal of Consumer Behaviour, Vol 7 No 4, pp. 315-332. 
Tables

Table 1 Clients and agencies in the cases

\begin{tabular}{|c|c|c|c|c|c|c|}
\hline Case & $\begin{array}{c}\text { Client } \\
\text { characteristics } \\
(\mathrm{T} / \mathrm{O} \text { in } \mathrm{GBP})\end{array}$ & $\begin{array}{c}\text { Agency } \\
\text { characteristics }\end{array}$ & $\begin{array}{l}\text { Relationship } \\
\text { duration }\end{array}$ & $\begin{array}{l}\text { Client } \\
\text { contact }\end{array}$ & $\begin{array}{l}\text { Agency: } \\
\text { Client } \\
\text { services } \\
\text { contact }\end{array}$ & $\begin{array}{l}\text { Agency: } \\
\text { Creative } \\
\text { services } \\
\text { contact }\end{array}$ \\
\hline 1 & $\begin{array}{l}\text { Beverages } \\
\text { wholesaler, } \mathrm{T} / \mathrm{O} \\
\text { f700m }\end{array}$ & $\begin{array}{l}\text { In-house agency, } \\
11 \text { people }\end{array}$ & N/A & $\begin{array}{l}\text { Marketing } \\
\text { manager, } 7 \\
\text { years' } \\
\text { experience, } \\
7 \text { years in } \\
\text { current role }\end{array}$ & $\begin{array}{l}\text { Head of } \\
\text { studio, } 12 \\
\text { years' } \\
\text { experience, } \\
2 \text { years in } \\
\text { current role }\end{array}$ & $\begin{array}{l}\text { Senior } \\
\text { creative, } \\
12 \text { years' } \\
\text { experience, } 3 \\
\text { years in } \\
\text { current role }\end{array}$ \\
\hline 2 & $\begin{array}{l}\text { Alcoholic } \\
\text { beverages } \\
\text { company, T/O } \\
£ 400 \mathrm{~m}\end{array}$ & $\begin{array}{l}\text { Founded } 2003, \\
15 \text { people. }\end{array}$ & $\begin{array}{l}10 \text { years and } \\
\text { on-going }\end{array}$ & $\begin{array}{l}\text { Brand } \\
\text { manager, } 13 \\
\text { years' } \\
\text { experience, } \\
3 \text { years in } \\
\text { current role }\end{array}$ & $\begin{array}{l}\text { Managing } \\
\text { director, } 30 \\
\text { years' } \\
\text { experience, } \\
10 \text { years in } \\
\text { current role }\end{array}$ & $\begin{array}{l}\text { Creative } \\
\text { director, } 17 \\
\text { years' } \\
\text { experience, } \\
10 \text { years in } \\
\text { current role }\end{array}$ \\
\hline 3 & $\begin{array}{l}\text { Food } \\
\text { manufacturer, } \\
\mathrm{T} / \mathrm{O} f 800 \mathrm{~m}\end{array}$ & 400 people & $\begin{array}{l}6 \text { years and } \\
\text { on-going }\end{array}$ & $\begin{array}{l}\text { Marketing } \\
\text { director, } 20 \\
\text { years' } \\
\text { experience, } \\
3 \text { years in } \\
\text { current role }\end{array}$ & $\begin{array}{l}\text { Account } \\
\text { director, } 9 \\
\text { years' } \\
\text { experience, } \\
5 \text { years in } \\
\text { current role }\end{array}$ & $\begin{array}{l}\text { Not permitted } \\
\text { to interview a } \\
\text { member of } \\
\text { the creative } \\
\text { team }\end{array}$ \\
\hline 4 & $\begin{array}{l}\text { B2B service, } T / O \\
\text { £25m }\end{array}$ & 20 people & $\begin{array}{l}2 \text { years and } \\
\text { on-going (but } \\
\text { client contact, } \\
\text { worked with } \\
\text { the agency in } \\
\text { a previous } \\
\text { role) }\end{array}$ & $\begin{array}{l}\text { Brand } \\
\text { manager, } 15 \\
\text { years' } \\
\text { experience, } \\
2 \text { years in } \\
\text { current role }\end{array}$ & $\begin{array}{l}\text { Account } \\
\text { manager, } 3 \\
\text { years' } \\
\text { experience, } \\
3 \text { years in } \\
\text { current role }\end{array}$ & $\begin{array}{l}\text { Middleweight } \\
\text { creative, } 8 \\
\text { years' } \\
\text { experience, } 8 \\
\text { years in } \\
\text { current role }\end{array}$ \\
\hline 5 & $\begin{array}{l}\text { Construction } \\
\text { firm, } T / O f 560 m\end{array}$ & $\begin{array}{l}\text { In house agency, } \\
11 \text { people }\end{array}$ & N/A & $\begin{array}{l}\text { Marketing } \\
\text { manager, } 20 \\
\text { years' } \\
\text { experience, } \\
17 \text { years in } \\
\text { current role }\end{array}$ & $\begin{array}{l}\text { Head of } \\
\text { studio, } 24 \\
\text { years' } \\
\text { experience, } \\
21 \text { years in } \\
\text { current role }\end{array}$ & $\begin{array}{l}\text { Senior } \\
\text { designer, } 16 \\
\text { years' } \\
\text { experience, } \\
11 \text { years in } \\
\text { current role }\end{array}$ \\
\hline 6 & $\begin{array}{l}\text { Service firm } \\
\text { (business and } \\
\text { consumer) } \\
T / 0 £ 65 \mathrm{~m}\end{array}$ & $\begin{array}{l}\text { Founded 1991, } \\
25 \text { people }\end{array}$ & $\begin{array}{l}9 \text { years and } \\
\text { on-going }\end{array}$ & $\begin{array}{l}\text { Marketing } \\
\text { director, } 30 \\
\text { years' } \\
\text { experience, } \\
9 \text { years in } \\
\text { current role }\end{array}$ & $\begin{array}{l}\text { Account } \\
\text { manager } 8 \\
\text { years' } \\
\text { experience, } \\
2 \text { years in } \\
\text { current role. } \\
\text { Account } \\
\text { director, } 10 \\
\text { years in } \\
\text { current role }\end{array}$ & $\begin{array}{l}\text { Creative } \\
\text { director, } 15 \\
\text { years' } \\
\text { experience, } 5 \\
\text { years in } \\
\text { current role }\end{array}$ \\
\hline 7 & $\begin{array}{l}\text { Same firm as } \\
\text { Case } 6\end{array}$ & $\begin{array}{l}\text { Founded } 1997, \\
55 \text { people }\end{array}$ & $\begin{array}{l}18 \text { months } \\
\text { and on-going }\end{array}$ & $\begin{array}{l}\text { Same } \\
\text { contact as } \\
\text { Case } 6\end{array}$ & $\begin{array}{l}\text { Account } \\
\text { director. }\end{array}$ & $\begin{array}{l}\text { Creative } \\
\text { director, } 14 \\
\text { years' } \\
\text { experience, } 3 \\
\text { years in } \\
\text { current role }\end{array}$ \\
\hline
\end{tabular}


2

3

4

5

6

7

8

9

\begin{tabular}{|l|l|l|l|l|l|l|}
\hline $\mathbf{8}$ & $\begin{array}{l}\text { Food } \\
\text { manufacturer, } \\
\text { T/O f250m }\end{array}$ & $\begin{array}{l}\text { Founded 1994, } \\
18 \text { people }\end{array}$ & $\begin{array}{l}5 \text { years and } \\
\text { on-going }\end{array}$ & $\begin{array}{l}\text { Brand } \\
\text { manager, 10 } \\
\text { years' } \\
\text { experience } \\
\text { and 10 years } \\
\text { in current } \\
\text { firm }\end{array}$ & $\begin{array}{l}\text { Account } \\
\text { manager, 11 } \\
\text { years' } \\
\text { experience, } \\
7 \text { years in } \\
\text { current role }\end{array}$ & $\begin{array}{l}\text { Creative } \\
\text { director, 17 } \\
\text { years' } \\
\text { experience, 8 } \\
\text { years in } \\
\text { current role }\end{array}$ \\
\hline $\mathbf{9}$ & $\begin{array}{l}\text { Same firm as } \\
\text { Case 8 }\end{array}$ & $\begin{array}{l}\text { Founded 2003, } \\
27 \text { people }\end{array}$ & $\begin{array}{l}5 \text { years and } \\
\text { on-going }\end{array}$ & $\begin{array}{l}\text { Same } \\
\text { contact as } \\
\text { Case 8 }\end{array}$ & $\begin{array}{l}\text { Managing } \\
\text { director }\end{array}$ & $\begin{array}{l}\text { Creative } \\
\text { director }\end{array}$ \\
\hline
\end{tabular}

Table 2 Topic Guides

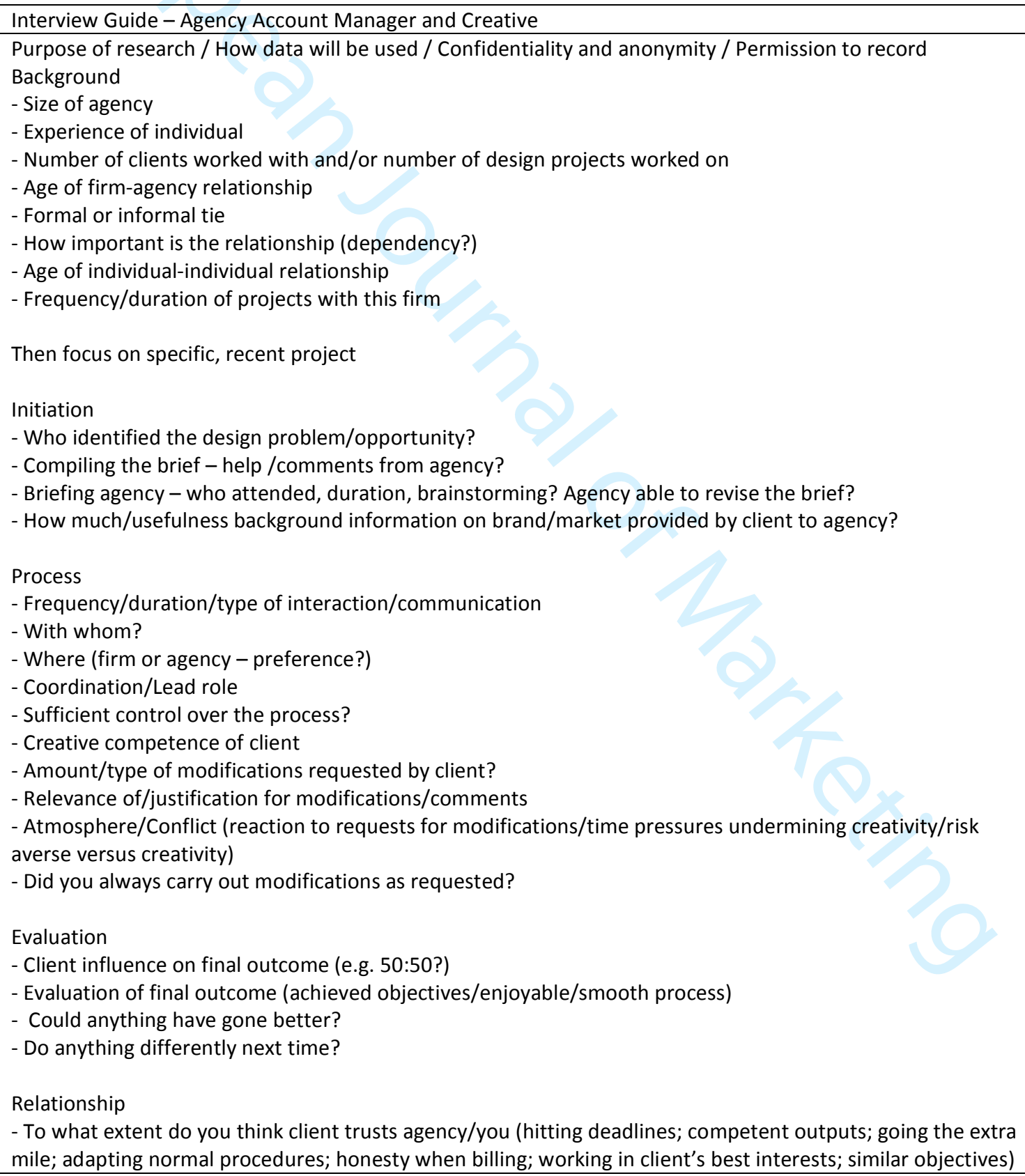


- Friendships? (Strictly work or informal chat and/or socialising outside office hours)

- Strength of relationship after project

Interview Guide - Client

Purpose of research / How data will be used / Confidentiality and anonymity / Permission to record

Background

- Size of firm

- Experience of individual

- Number of agencies worked with and/or number of design projects worked on

- Describe yourself as creative?

- Age of firm-agency relationship

- Formal or informal tie

- How important is the relationship (dependency?)

- Age of individual-agency relationship

- Frequency/duration of projects with this agency

Then focus on specific, recent project

Initiation

- Who identified the design problem/opportunity?

- Importance of project

- Compiling the brief - help /comments from agency?

- Briefing agency - who attended, duration, brainstorming?

- How much background information on brand/market provided to agency?

- How confident that agency can deliver?

Process

- Frequency/duration/type of interaction/communication

- With whom?

- Where (firm or agency - why?)

- Why? (market knowledge input/customization/efficiency/creative input/enjoyment)

- Coordination/Lead role

- Sufficient control over the process?

- How easy/difficult to make suggestions and request modifications?

- Atmosphere/Conflict (reaction to requests for modifications/time pressures undermining creativity/risk averse versus creativity)

- Demands on time/emotion

Evaluation

- Client influence on final outcome (e.g. 50:50?)

- Evaluation of final outcome (achieved objectives/enjoyable/smooth process)

- Could anything have gone better?

- Do anything differently next time?

Relationship

- Level of trust in agency (hitting deadlines; competent outputs; going the extra mile; adapting their normal procedures; honesty when billing; working in your best interests; similar objectives)

- Friendships? (Strictly work or informal chat and/or socialising outside office hours)

- Strength of relationship after project

- Intention to work together again? 
2

3

4

5

6

7

8

9

\section{Table 3 Practitioner workshops and presentations}

\begin{tabular}{|l|l|l|}
\hline Event & Content & Participants \\
\hline Workshop 1 & $\begin{array}{l}\text { Full day workshop including presentation of initial } \\
\text { findings, group discussions of findings, feedback from } \\
\text { groups and discussion }\end{array}$ & 56 agency practitioners \\
\hline Workshop 2 & $\begin{array}{l}\text { Full day workshop including presentation of initial } \\
\text { findings, group discussions of findings, feedback from } \\
\text { groups and discussion }\end{array}$ & 11 client practitioners \\
\hline Workshop 3 & $\begin{array}{l}\text { Half day workshop including presentation of summary of } \\
\text { discussion in workshops 1 and 2. Further discussion and } \\
\text { plenary session. }\end{array}$ & $\begin{array}{l}36 \text { agency and client } \\
\text { practitioners }\end{array}$ \\
\hline $\begin{array}{l}\text { Eight separate } \\
\text { workshops with } \\
\text { individual agencies: } \\
\begin{array}{l}\text { August - November } \\
\text { 2015 }\end{array}\end{array}$ & $\begin{array}{l}\text { Presentation of findings to agency personnel and } \\
\text { discussion of implications for the agency and actions that } \\
\text { they might take }\end{array}$ & $\begin{array}{l}\text { A total of 108 agency } \\
\text { practitioners }\end{array}$ \\
\hline
\end{tabular}

Table 4 Operant Resources in client/agency co-creation

\begin{tabular}{|l|l|}
\hline Operant resources & Explanation \\
\hline Knowledge of client & -Understanding the way the organisation operates, its products, \\
distribution, profitability, commercial operations. \\
-Understanding of the organisational structure, decision-making and \\
constraints \\
-Knowledge of competitors, collaborators and operation of the markets in \\
which the organisation operates
\end{tabular}




\section{Figures}

Figure 1: Resource integration framework

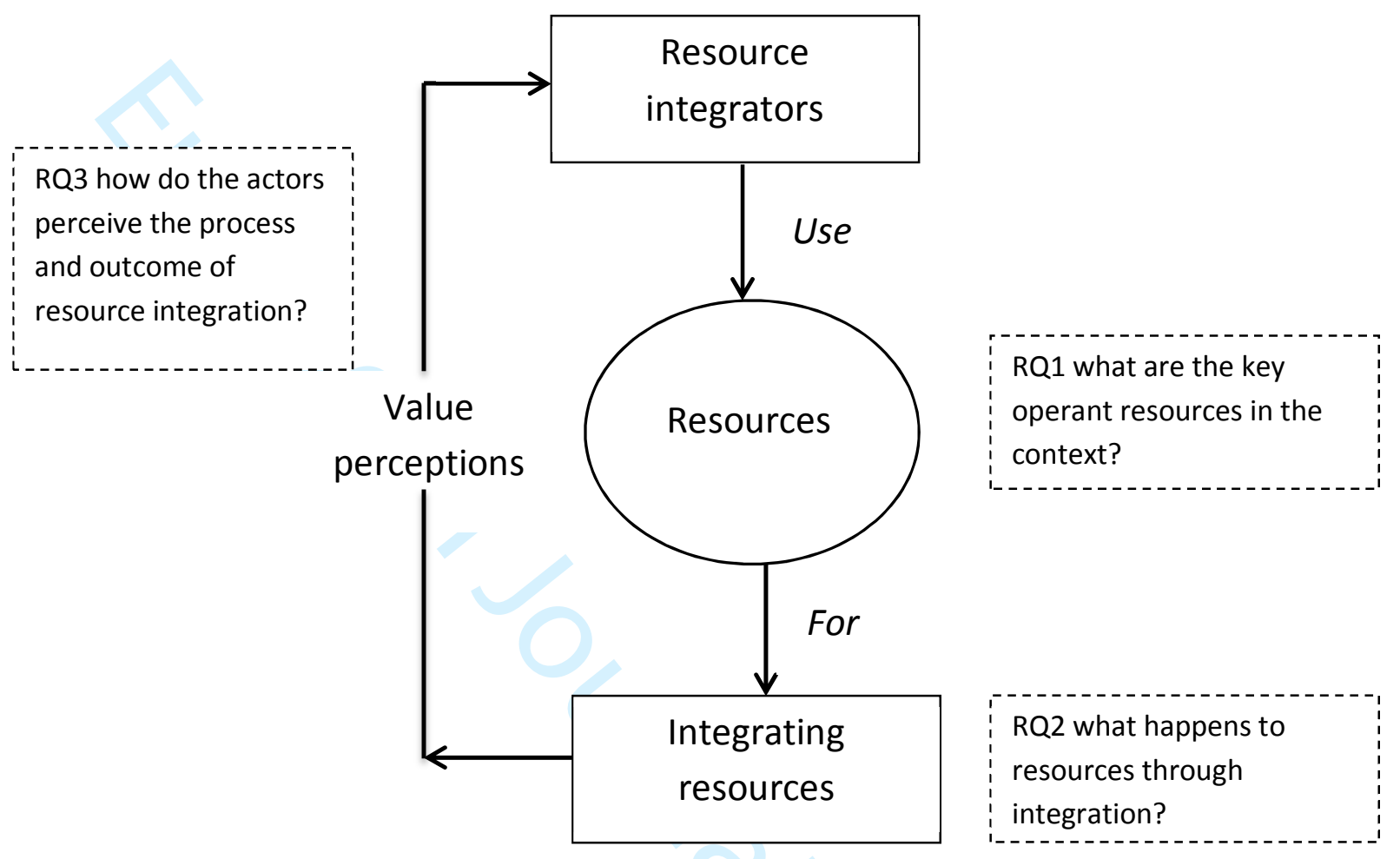

Source: Adapted from Kleinaltenkamp et al. (2012) 
2

3

4

5

6

7

8

9

Figure 2 Resource integrating: Operant resources

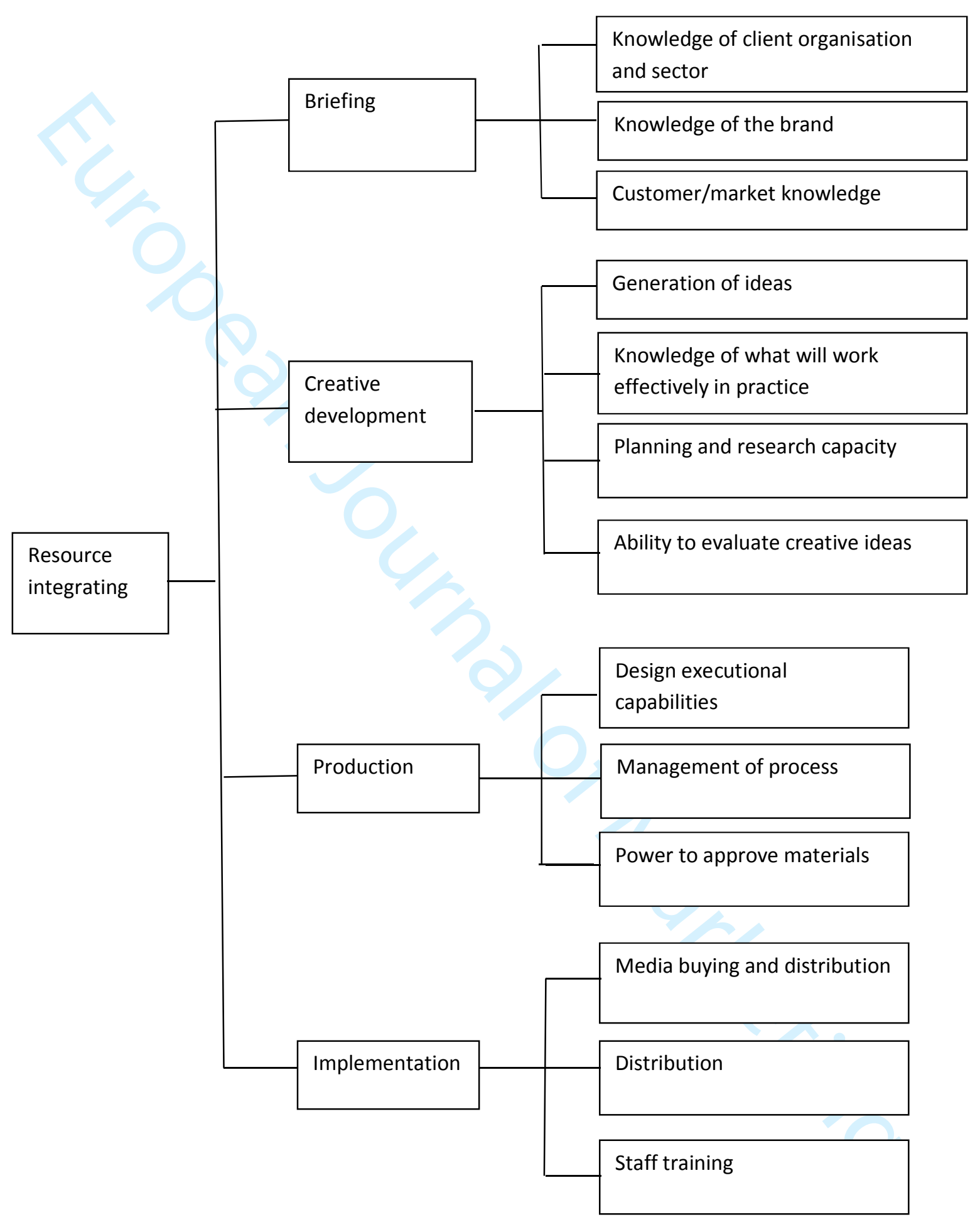


Figure 3 Resource development

10

11

12

13

14

15

16

17

18

19

20

21

22

23

24

25

26

27

28

29

30

31

32

33

34

35

36

37

38

39

40

41

42

43

44

45

46

47

48

49

50

51

52

53

54

55

56

57

58

59

60
Actors' resources with potential

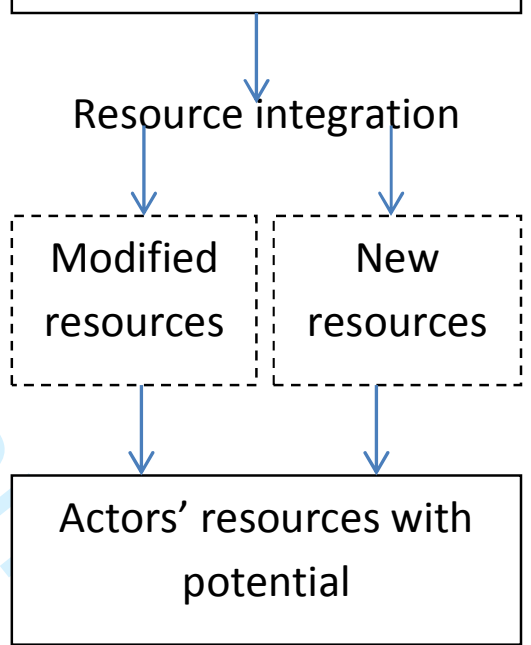

